\title{
PENERAPAN FUZZY TSUKAMOTO DALAM MENENTUKAN JUMLAH PRODUKSI SABUN DI PT. JAMPALAN BARU BERDASARKAN JUMLAH PERMINTAAN DAN DATA PERSEDIAAN
}

\author{
Ria Rahmadita Surbakti ${ }^{1}$, Marlina Setia Sinaga ${ }^{2}$ \\ ${ }^{1,2}$ Fakultas Matematika dan Ilmu Pengetahuan Alam \\ Universitas Negeri Medan \\ e-mail : riarahmadita@gmail.com
}

\begin{abstract}
ABSTRAK
Penelitian ini dilakukan di PT. Jampalan Baru Asahan yang merupakan perusahaan swasta yang bergerak dibidang produksi sabun.Permintaan pasar terhadap sabun tidak menentu setiap bulannya, sehingga persediaan sabun tidak dapat dipastikan yang berakibat produksi sabun yang dilakukan oleh PT. Jampalan Baru Asahan tidak dapat ditentukan secara pasti.Penelitian ini bertujuan untuk mengoptimalkan produksi sabun setiap bulannya dengan mengaplikasikan metode Tsukamoto logika fuzzy agar tidak mengalami kelebihan atau kekurangan persediaan. Jumlah optimal diperoleh dengan menghitung nilai output crisp dengan menggunakan defuzzifikasi metode rata-rata terpusat. Dari hasil penelitian yang telah dilakukan, dengan memasukkan variabel input pada bulan Desember 2016, yaitu jumlah permintaan sebesar 163800 pack dan jumlah persediaan sebesar 19500 pack menghasilkan output jumlah produksi sebesar 151043 pack.
\end{abstract}

Kata kunci : Logika Fuzzy, Metode Tsukamoto, Optimal, defuzzifikasi

\begin{abstract}
This research was conducted at PT. Asahan Asah's new journey is a private company engaged in soap production. The market demand for soap is erratic every month, so the supply of soap can not be ascertained which results in soap production made by PT. Jampalan Baru Asahan's can not be determined with certainty. This study aims to optimize the production of soap every month by applying the method of Tsukamoto logic fuzzy in order not to experience the advantages or lack of perse. The optimal number is obtained by calculating the output value of crisp using the centralized mean method defuzzification. From the results of research that has been done, by entering input variables in December 2016, namely the number of requests amounted to 163800 pack and the amount of inventory of 19500 pack produced output production amount of 151043 pack.
\end{abstract}

Keywords: Fuzzy Logic, Tsukamoto Method, Optimal, defuzzification 


\section{Pendahuluan}

Saat ini tingkat persaingan antar perusahaan semakin kompetitif. Oleh karena itu, perusahaan harus merencanakan jumlah produksi agar dapat memenuhi permintaan pasar tepat waktu dengan jumlah yang sesuai sehingga keuntungan perusahaan akan meningkat. Terkadang banyaknya jumlah permintaan pasar tidak sebanding dengan jumlah produksi perusahaan, sehingga muncul ketidak-pastian dalam menentukan jumlah produksi tersebut.Dengan adanya ketidakpastian tersebut, maka perusahaan harus menentukan jumlah produksi yang optimum.

Perusahaan PT. Jampalan Baru didirikan pada tahun 1978 dan beralamat di km 10 Desa Jampalan, Kecamatan Simpang Empat, Kabupaten Asahan, Provinsi Sumatera Utara. PT. Jampalan Baru bergerak dibidang produksi sabun, pengemasan minyak dan penggilingan padi.

Pemasalahan yang timbul dari perusahaan ini adalah kesulitan dalam prediksi jumlah produksi untuk bulan-bulan berikutnya.Kebutuhan konsumen selalu berubah-ubah dalam arti konsumsi per hari bahkan per bulannya selalu berbeda.Sehingga terjadi hubungan yang saling berkaitan antara permintaan, persediaan dan jumlah produksi. Banyaknya jumlah yang akan diproduksi dipengaruhi oleh banyaknya permintaan pasar dan banyaknya persediaan di gudang perusahaan tersebut. Oleh karena itu, cukup sulit untuk menentukan jumlah produksi yang tepat untuk memenuhi permintaan pasar tepat waktu dengan jumlah yang sesuai.Untuk menentukan jumlah produksi ini, dapat dilakukan dengan menggunakan logika fuzzy.

Logika fuzzy merupakan salah satu komponen pembentuk soft computing.Logika fuzzy pertama kali diperkenalkan oleh Prof. Lotfi A. Zadeh pada tahun 1965.Dasar logika fuzzy adalah teori himpunan Fuzzy.Pada teori himpunan fuzzy, peranan derajat keanggotaan sebagai penentu keberadaan elemen dalam suatu himpunan sangat penting.Nilai keanggotaan atau membership function menjadi ciri utama dari penalaran dengan logika fuzzy tersebut. Logika fuzzy adalah suatu cara yang tepat untuk memetakan suatu ruang input ke dalam suatu ruang output [1].

Salah satu penerapan logika fuzzy adalah dalam ilmu ekonomi, yaitu penggunaan Sistem Inferensi Fuzzy dalam penentuan jumlah produksi.Ilmu ekonomi yang mempelajari tentang perencanaan produksi dalam hal penentuan jumlah produksi adalah manajemen operasi.Secara umum, manajemen operasi diartikan sebagai pengarahan dan pengendalian 
KARISMATIKA

VOL. 4 NO. 1 APRIL 2018

p-ISSN : $2443-0366$

e-ISSN : 2528 -- 0279

berbagai kegiatan yang mengolah berbagai jenis sumber daya untuk membuat barang atau jasa tertentu [2].

Ada tiga metode dalam sistem inferensi fuzzy yang dapat digunakan untuk menentukan jumlah produksi, yaitu : metode Tsukamoto, metode Mamdani, dan metode Sugeno. Adapun metode yang dipilih dalam penelitian ini adalah metode Tsukamoto.Metode Tsukamoto dipilih karena merupakan suatu metode yang dapat memprediksi dan memberi toleransi terhadap data yang tidak tepat misalkan data permintaan dan persediaan yang sangat fleksibel dan fluktuatif.. Pada metode Tsukamoto, setiap konsekuen pada aturan yang berbentuk IF-THEN harus direpre-sentasikan dengan suatu himpunan fuzzy dengan fungsi keanggotaan yang monoton.Sebagai hasilnya, output hasil inferensi dari tiap-tiap aturan diberikan secara tegas (crisp) berdasarkan -predikat (fire strength) [3].

\section{Landasan Teori}

\subsection{Logika dan Himpunan Fuzzy $([3,4,5,6])$}

Logika fuzzy adalah himpunan yang setiap unsur-unsurnya mempunyai derajat keanggotaan atau kesesuaian dengan konsep yang merupakan syarat keanggotaan himpunan tersebut. Logika fuzzy digunakan sebagai suatu cara untuk memetakan permasalahan dari input menuju ke output yang diharapkan. Logika fuzzy pertama sekali diperkenalkan oleh Lotfi. A. Zadeh pada tahun 1965. Dasar logika fuzzy adalah teori himpunan fuzzy. Dalam teori himpunan dikenal fungsi karakteristik yaitu fungsi dari himpunan semesta $\mathrm{X}$ ke himpunan $\{0,1\}$.

Definisi : Himpunan A dalam semesta $X$ dapat dinyatakandengan fungsi karakteristik yang $\chi_{A}: X \rightarrow\{0,1\}$ didefinisikan dengan aturan :

$$
\chi_{A}(x)=\left\{\begin{array}{lll}
1 & \text { untuk } x & \in A \\
0 & \text { untuk } x & \notin A
\end{array} \quad \forall x \in X\right.
$$

Teori himpunan yang telah lama dikenal ini selanjutnya disebut sebagai himpunan tegas (crisp set). Pada himpunan tegas (crisp), nilai keanggotaan suatu item $\mathrm{x}$ dalam suatu himpunan $A$, yang sering ditulis dengan $\mu_{A}(x)$, memiliki dua kemungkinan yaitu :

1. Satu (1), yang berarti bahwa suatu item menjadi anggota dalam suatu himpunan.

2. Nol (0), yang berarti bahwa suatu item tidak menjadi anggota dalam suatu himpunan. 


\subsection{Fungsi Keanggotaan Fuzzy}

Fungsi Keanggotaan (membership function) adalah suatukurva yang menunjukkan pemetaan titik-titik input data ke dalam nilai keanggotaannya (sering juga disebut dengan derajat keanggotaan) yang memiliki interval antara 0 sampai 1. Salah satu cara yang dapat digunakan untuk mendapatkan nilai keanggotaan adalah dengan melalui pendekatan fungsi. Ada beberapa fungsi yang bisa digunakan.

\section{Representasi Linear}

Ada 2 keadaan himpunan fuzzy yang linear.Pertama, kenaikan himpunan dimulai pada nilai domain yang memiliki derajat keanggotaan nol [0] bergerak ke kanan menuju ke nilai domain yang memiliki derajat keanggotaan lebih tinggi.

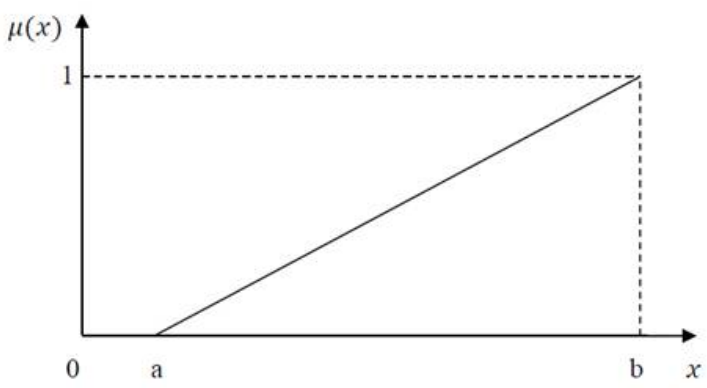

Gambar 2.1 Representasi Linear Naik

Fungsi Keanggotaan :

$$
\mu[x]=\left\{\begin{array}{cc}
0 ; & x \leq a \\
\frac{(x-a)}{(b-a)} ; & a \leq x \leq b \\
1 ; & x \geq b
\end{array}\right.
$$

Kedua, merupakan kebalikan yang pertama.Garis lurus dimulai dari nilai domain dengan derajat keanggotaan tertinggi pada sisi kiri, kemudian bergerak menurun ke nilai domain yang memiliki derajat keanggotaan lebih rendah. 
KARISMATIKA

VOL. 4 NO. 1 APRIL 2018

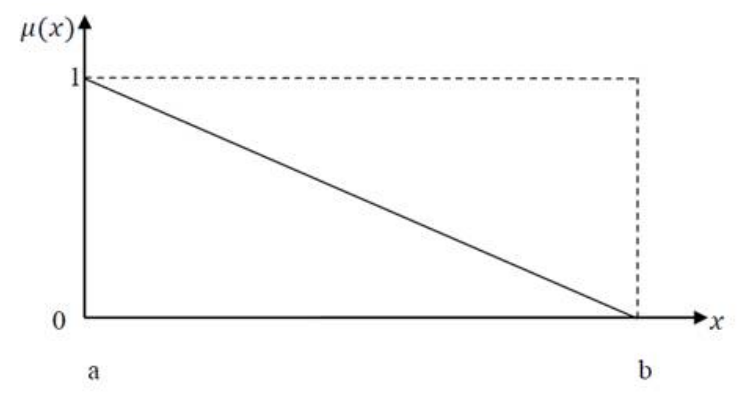

p-ISSN : 2443 - 0366

e-ISSN : 2528 -- 0279

Gambar 2.2 Representasi Linear Turun

Fungsi Keanggotaan :

$$
\mu[x]=\left\{\begin{array}{cc}
1 ; & x \leq a \\
\frac{(b-x)}{(b-a)} ; & a \leq x \leq b \\
0 ; & x \geq b
\end{array}\right.
$$

\section{Representasi Kurva Segitiga}

Kurva Segitiga pada dasarnya merupakan gabungan antara 2 garis (linear turun dan naik).

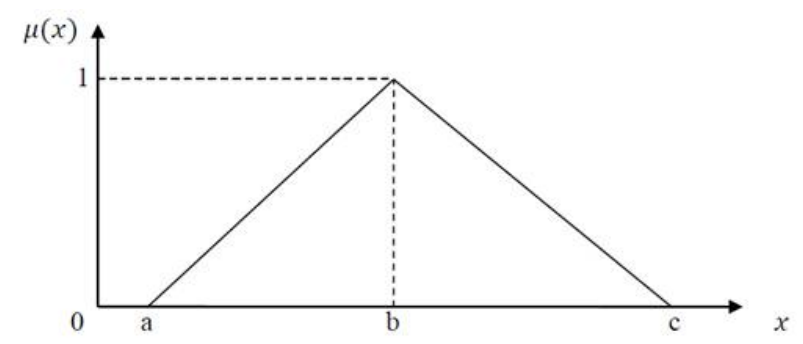

Gambar 2.3 Representasi Kurva Segitiga Fungsi Keanggotaan :

$$
\mu[x]=\left\{\begin{array}{c}
0 ; x \leq \text { atau } x \geq c \\
\frac{(x-a)}{(b-a)} ; a \leq x \leq b \\
\frac{(c-x)}{(c-b)} ; b \leq x \leq c
\end{array}\right.
$$

\section{Operator dasar himpunan fuzzy}

Ada 3 operator dasar yang diciptakan oleh Zadeh [1] yaitu:

\section{Operator AND}


KARISMATIKA

VOL. 4 NO. 1 APRIL 2018

p-ISSN : $2443-0366$

e-ISSN : 2528 -- 0279

Operator ini berhubungan dengan operasi interseksi pada himpunan. $\alpha$ - predikat sebagai hasil operasi dengan operator AND diperoleh dengan mengambil nilai keanggotaan terkecil antar elemen pada himpunan-himpunan yang bersangkutan.

$$
\mu_{A \cap B}=\min \left(\mu_{A}[x], \mu_{A}[y]\right)
$$

\section{Operator OR}

Operator ini berhubungan dengan operasi union pada himpunan. $\alpha$-predikat sebagai hasil operasi dengan operator OR diperoleh dengan mengambil nilai keanggotaan terbesar antar elemen pada himpunan-himpunan yang bersangkutan.

$$
\mu_{A \cup B}=\max \left(\mu_{A}[x], \mu_{A}[y]\right)
$$

\section{Operator NOT}

Operator ini berhubungan dengan operasi komplemen pada himpunan. $\alpha$ - predikat sebagai hasil operasi dengan operator NOT diperoleh dengan mengurangkan nilai keanggotaan elemen pada himpunan yang bersangkutan dari 1 .

$$
\mu_{A^{\prime}}=1-\mu_{A}[x]
$$

\subsection{Metode Tsukamoto}

Metode Tsukamoto merupakan perluasan dari penalaran monoton.Pada metode Tsukamoto, setiap konsekuen pada aturan yang berbentuk If-Then harus direpresentasikan dengan suatu himpunan fuzzy dengan fungsi keanggotaan yang monoton.Sebagai hasilnya, output hasil inferensi dari tiap-tiap aturan diberikan secara tegas (crisp) berdasarkan $\propto$-predikat. Hasil akhirnya diperoleh dengan menggunakan rata-rata terbobot [1].

Secara umum terdapat tiga langkah untuk menentukan jumlah produksi berdasarkan data persediaan dan data permintaan dengan metode Tsukamoto, yaitu: mendefinisikan variabel, inferensi, dan deffuzzifikasi (menentukan output crisp).

\section{Metodelogi Penelitian}

Penelitian ini dilakukan di PT. Jampalan Baru yang beralamat di km 10 Desa Simpang Empat, Kecamatan Simpang Empat, Kabupaten Asahan, Provinsi Sumatera Utara dan waktu penelitian kurang lebih selama dua bulan.Jenis penelitian ini adalah studi kasus pada PT. Jampalan Baru.

Adapun langkah-langkah yang dilakukan dalam penelitian ini, antara lain : 
KARISMATIKA

VOL. 4 NO. 1 APRIL 2018

p-ISSN : $2443-0366$

e-ISSN : 2528 -- 0279

1. Mengumpulkan data

Data jumlah permintaan dari PT. Jampalan Baru di bulan Januari 2016 - Desember 2016.

Data jumlah persediaan dari PT. Jampalan Baru di bulan Januari 2016 - Desember 2016.

Data jumlah produksi dari PT. Jampalan Baru di bulan Januari 2016 - Desember 2016.

2. Menganalisis data

Adapun analisis yang dilakukan setelah data terkumpul, antara lain :

(a) Mendefinisikan variabel input dan output.

Pada penelitian ini, terdapat duavariabel input, yaitu : permintaan dan persediaan, sedangkan variabel output : produksi.

(b) Mendefinisikan variabel menjadihimpunan fuzzy

Dari variabel input dibentuk himpunan fuzzy, antara lain :

- Variabel Permintaan, terdiri dari 3 himpunan fuzzy : Turun, Tetap dan Naik.

- Variabel Persediaan, terdiri dari 3 himpunan fuzzy : Sedikit, Sedang dan Banyak.

Dari variabel output, dibentuk himpunan fuzzy, yaitu :

- Variabel Produksi, terdiri dari 3 himpunan fuzzy : Berkurang, Tetap dan Bertambah.

(c) Pembentukan Aturan Fuzzy

Dari kedua variabel input dan sebuah variabel output yang telah didefinisikan, dengan melakukan analisa data terhadap batas tiap-tiap himpunan fuzzy pada tiap-tiap variabelnya maka dibentuk 9 aturan fuzzy.

(d) Proses Logika Fuzzy

- Fuzzifikasi

Menentukan derajat keanggotaan dari sebuah nilai numerik masukan (crisp).

- Aplikasi fungsi implikasi

Menggunakan fungsi MIN sebagai metode implikasinya dalam menentukan $\alpha$-predikat minimum dari tiap-tiap aturan yang ditetapkan.

- Defuzzifikasi

Untuk menentukan outputcrisp, digunakan defuzzi-fikasi rata-rata terpusat. 
KARISMATIKA

VOL. 4 NO. 1 APRIL 2018
p-ISSN : $2443-0366$

e-ISSN : 2528 -- 0279

(e) Menarik kesimpulan dari hasil pengolahan data.

\section{Hasil Dan Pembahasan}

Penyelesaian masalah optimasi produksi barang akan menggunakan logika fuzzy, yaitu dengan menggunakan metode Tsukamoto.

\section{Data}

Data yang digunakan sebagai variabel dalam penelitian ini berupa data jumlah permintaan sabun, persediaan sabun serta data jumlah produksi sabun yang harus diproduksi oleh PT. Jampalan Baru selama satu tahun terakhir.Berikut merupakan data yang diperoleh dari PT. Jampalan Baru dalam kurun waktu antara Januari 2016 sampai Desember 2016.

Tabel 1 Data Permintaan, Persediaan, dan Produksi Sabun PKS Kuning di PT. Jampalan Baru Tahun 2016

\begin{tabular}{|l|r|r|r|}
\hline Bulan & Permintaan & Persediaan & \multicolumn{1}{l|}{ Produksi } \\
\hline Januari & 127400 & 9100 & 130000 \\
\hline Februari & 146400 & 18000 & 130800 \\
\hline Maret & 148500 & 21600 & 132300 \\
\hline April & 125000 & 8750 & 131250 \\
\hline Mei & 168750 & 21600 & 155250 \\
\hline Juni & 169000 & 7800 & 165000 \\
\hline Juli & 166400 & 23500 & 148200 \\
\hline Agustus & 153900 & 9315 & 156050 \\
\hline September & 153400 & 22100 & 137800 \\
\hline Oktober & 158600 & 10400 & 154440 \\
\hline November & 156000 & 7800 & 164700 \\
\hline Desember & 163800 & 19500 & 150800 \\
\hline
\end{tabular}

\section{Pengolahan Data}

\section{Mendefinisikan Variabel Input dan Output}

Pengolahan data dimulai dengan menentukan variabel input dan output serta membentuk himpunan fuzzy. Variabel input merupakan data permintaan sabun dan persediaan sabun, variabel output merupakan jumlah produksi sabun. Himpunan fuzzy yang dibentuk untuk setiap variabel adalah sebagai berikut:

a. Permintaan sabun, terdiri atas 3 himpunan fuzzy, yaitu : Turun, Tetap, dan Naik

b. Persediaan sabun, terdiri atas 3 himpunan fuzzy, yaitu : Sedikit, Sedang, dan Banyak 
KARISMATIKA

p-ISSN : 2443 - 0366

VOL. 4 NO. 1 APRIL 2018

c. Produksi sabun, terdiri atas 3 himpunan fuzzy, yaitu : Berkurang, Tetap, dan Bertambah.

\section{Representasi dan Fungsi Variabel}

Representasi fungsi variabel menggunakan dua jenis kurva, yaitu representasi kurva linear dan representasi kurva segitiga. Setiap kurva yang digunakan memiliki fungsi variabel yang akan digunakan untuk menghitung derajat keanggotaan masing-masing anggota himpunan dari setiap variabel tersebut.

1. Variabel permintaan $(\mathrm{x})$

Untuk merepresentasikan variabel permintaan dan untuk membuat fungsi dari variabel tersebut, digunakan kurva berbentuk segitiga (untuk himpunan Tetap) dan kurva linear (untuk himpunan Turun dan Naik), Seperti terlihat pada gambar berikut :

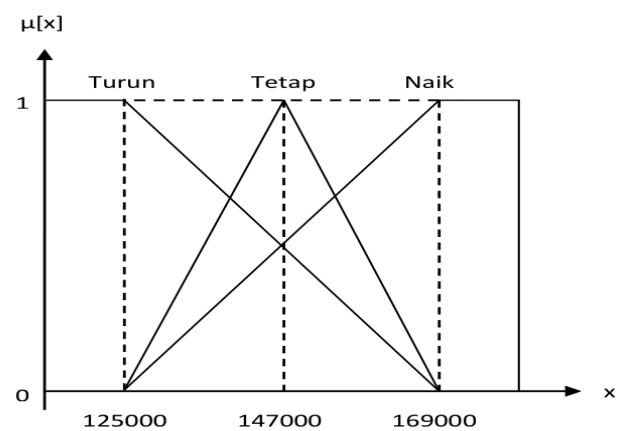

Gambar 1 Representasi VariabelPermintaan

Sesuai data yang diperoleh, permintaan disebut menurun pada jumlah 125000 dan permintaan sangat tinggi pada jumlah 169000. Permintaan rata-rata yang terjadi setiap bulannya adalah: 147000. Fungsi yang diperoleh :

$$
\begin{aligned}
& \text { upmtTurun }[x]=\left\{\begin{aligned}
\frac{(169000-x)}{(44000)}, & 125000 \leq x \leq 169000 \\
0, & x \geq 169000
\end{aligned}\right. \\
& \operatorname{\mu pmtTetap}[x]=\left\{\begin{aligned}
& \frac{(x-125000)}{(22000)}, 125000 \leq x \leq 147000 \\
& \frac{(169000-x)}{(22000)}, 147000 \leq x \leq 169000 \\
& 0, x \leq 169000 \text { atau } x \geq 169000
\end{aligned}\right. \\
& \text { upmtNaik }[x]=\left\{\begin{aligned}
\frac{(x-125000)}{(44000)}, & 125000 \leq x \leq 169000 \\
1, & x \geq 169000
\end{aligned}\right.
\end{aligned}
$$




\section{2. $\quad$ Variabel Persediaan Sabun (y)}

Untuk merepresentasikan variabel persediaan dan untuk membuat fungsi dari variabel tersebut, digunakan kurva berbentuk segitiga (untuk himpunan Sedang) dan kurva linear (untuk himpunan Sedikit dan Banyak), Seperti terlihat pada gambar berikut :

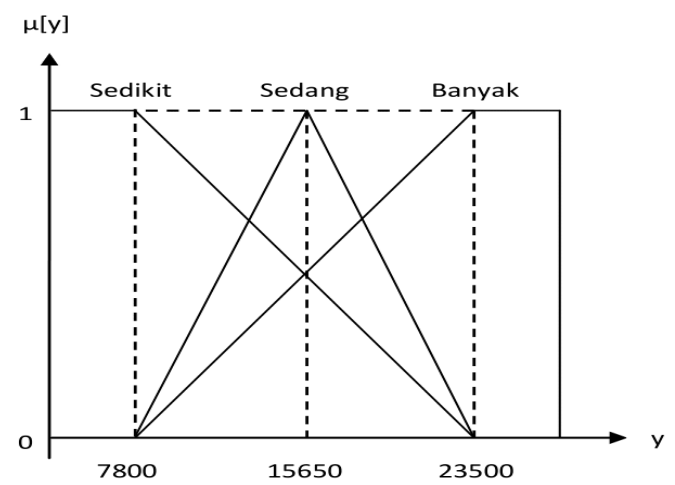

Gambar 2 Representasi Variabel Persediaan

Sesuai data yang diperoleh, persediaan disebut menurun pada jumlah 7800 dan persediaan sangat tinggi pada jumlah 23500.Persediaan rata-rata yang terjadi setiap bulannya adalah 15650. Berdasarkan data persediaan tersebut diperoleh fungsi himpunan sebagai berikut :

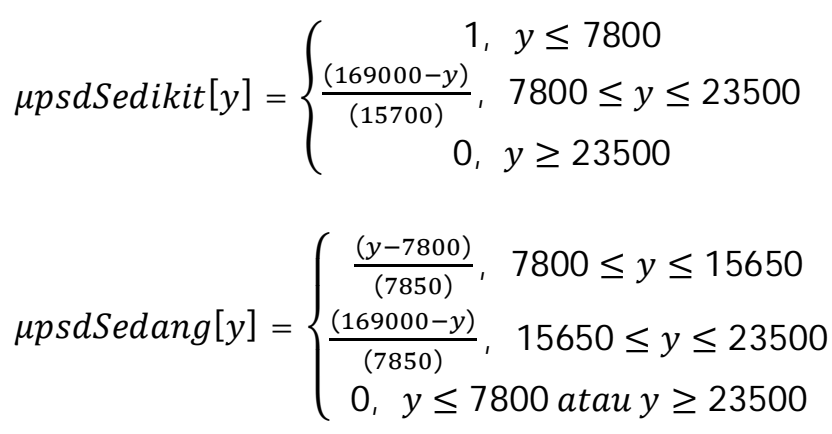

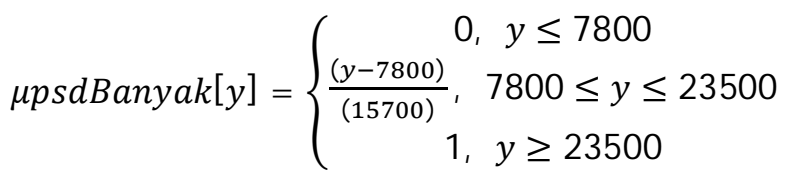

\section{Variabel Produksi Sabun (z)}

Untuk merepresentasikan variabel pemesanan dan untuk membuat fungsi dari variabel tersebut, digunakan kurva berbentuk segitiga (untuk himpunan Tetap) dan kurva linear (untuk himpunan Berkurang dan Bertambah), seperti terlihat pada gambar berikut : 
KARISMATIKA

VOL. 4 NO. 1 APRIL 2018
p-ISSN : $2443-0366$

e-ISSN : 2528 -- 0279

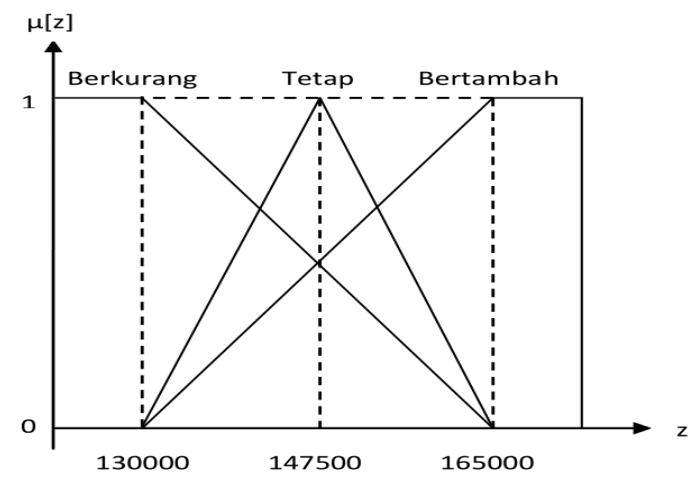

Gambar 3 Representasi Variabel Produksi

$\mu p r d B e r k u r a n g[z]=\left\{\begin{array}{c}1, z \leq 130000 \\ \frac{(165000-z)}{(35000)}, \quad 130000 \leq z \leq 165000 \\ 0, z \geq 165000\end{array}\right.$

$\operatorname{\mu prdTetap}[z]=\left\{\begin{array}{l}\frac{(z-130000)}{(17500)}, 130000 \leq z \leq 147500 \\ \frac{(165000-z)}{(17500)}, 147500 \leq z \leq 165000 \\ 0, z \leq 130000 \text { atau } z \geq 165000\end{array}\right.$

$\mu \operatorname{prdBertambah}[z]=\left\{\begin{array}{c}0, z \leq 130000 \\ \frac{(z-13000)}{(17500)}, \quad 130000 \leq z \leq 165000 \\ 1, \quad z \geq 165000\end{array}\right.$

\section{Menentukan Aturan Logika Fuzzy}

Pembentukan aturan fuzzy dari kedua variabel input dan sebuah variabel output yang telah di definisikan, dengan melakukan analisa data terhadap batas tiap-tiap himpunan fuzzy pada tiap-tiap variabelnya maka dibentuk 9 aturan fuzzyyaitu :

(R1). Jika Permintaan TURUN dan Persediaan BANYAK maka Produksi Barang BERKURANG

(R2). Jika Permintaan TURUN dan Persediaan SEDANG maka Produksi Barang BERKURANG

(R3). Jika Permintaan TURUN dan Persediaan SEDIKIT maka Produksi Barang BERKURANG; 
KARISMATIKA

p-ISSN : $2443-0366$

VOL. 4 NO. 1 APRIL 2018

e-ISSN : 2528 -- 0279

(R4). Jika Permintaan TETAP dan Persediaan BANYAK maka Produksi Barang BERKURANG;

(R5). Jika Permintaan TETAP dan Persediaan SEDANG maka Produksi Barang TETAP;

(R6). Jika Permintaan TETAP dan Persediaan SEDIKIT maka Produksi Barang BERTAMBAH;

(R7). Jika Permintaan NAIK dan Persediaan BANYAK maka Produksi Barang BERTAMBAH;

(R8). Jika Permintaan NAIK dan Persediaan SEDANG maka Produksi Barang BERTAMBAH;

(R9). Jika Permintaan NAIK dan Persediaan SEDIKIT maka Produksi Barang BERTAMBAH

\section{Perhitungan Data Desember 2016}

Pada Desember 2016, PT. Jampalan Baru memiliki jumlah permintaan sabun sebesar 163800 pack dan memiliki persediaan sebesar 19500 pack. Maka berikut akan diperkirakan berapa jumlah sabun yang harus diproduksi oleh PT. Jampalan Baru dengan menggunakan Fuzzy Tsukamoto.

\section{Menentukan Derajat Keanggotaan}

Jika jumlah permintaan sabun sebanyak 163800 pack, maka nilai keanggotaan Fuzzy pada tiap-tiap himpunan adalah:

- Himpunan Fuzzy Turun diperoleh dari:

$$
\mu \text { Pmt Turun }[163800]=\frac{169000-163800}{44000}=0,118
$$

- Himpunan Fuzzy Tetap diperoleh dari:

$$
\mu P m t \text { Tetap }[163800]=\frac{169000-163800}{22000}=0,236
$$

- Himpunan Fuzzy Naik diperoleh dari:

$$
\mu \text { Pmt Naik[163800] }=\frac{163800-125000}{44000}=0,882
$$


Apabila jumlah persediaan sabun sebesar 19500 pack, maka nilai keanggotaan pada tiap-tiap himpunan adalah:

- Himpunan Fuzzy Sedikit diperoleh dari:

$$
\mu \text { Psd Sedikit }[19500]=\frac{23500-19500}{15700}=0,255
$$

- Himpunan Fuzzy Sedang diperoleh dari:

$$
\mu \text { Psd Sedang }[19500]=\frac{23500-19500}{7850}=0,51
$$

- Himpunan Fuzzy Banyak diperoleh dari:

$$
\mu P s d \text { Banyak }[19500]=\frac{19500-7800}{15700}=0,745
$$

\section{Aplikasi Aturan Fuzzy}

a.Aturan ke-1

([R1]) Jika Permintaan TURUN dan Persediaan BANYAK maka Produksi Barang BERKURANG;

Operator yang digunakan adalah AND, sehingga:

$$
\begin{gathered}
\propto_{1}=\mu_{\text {PmtTurun }} \cap \mu_{\text {PsdBanyak }} \\
=\min \left(\mu_{\text {PmtTurun }}[163800], \mu_{\text {PsdBanyak }}[19500]\right) \\
=\min (0,118 ; 0,745) \\
=0,118 \\
z_{1}=165000-\left(\propto_{1}\right)(35000) \\
=165000-(0,118)(35000) \\
=160870
\end{gathered}
$$

b. Aturan ke-2

([R2]) Jika Permintaan TURUN dan Persediaan SEDANG maka Produksi Barang BERKURANG;

Operator yang digunakan adalah AND, sehingga:

$$
\propto_{2}=\mu_{\text {PmtTurun }} \cap \mu_{\text {PsdSedang }}
$$


KARISMATIKA

p-ISSN : $2443-0366$

VOL. 4 NO. 1 APRIL 2018

$$
\begin{gathered}
=\min \left(\mu_{\text {PmtTurun }}[163800], \mu_{\text {PsdSedang }}[19500]\right) \\
=\min (0,118 ; 0,51) \\
=0,118 \\
z_{2}=165000-\left(\propto_{2}\right)(35000) \\
=165000-(0,118)(35000) \\
=160870
\end{gathered}
$$

c.Aturan ke-3

([R3]) Jika Permintaan TURUN dan Persediaan SEDIKIT maka Produksi Barang

BERKURANG;

Operator yang digunakan adalah AND, sehingga:

$$
\begin{gathered}
\propto_{3}=\mu_{\text {PmtTurun }} \cap \mu_{\text {PsdSedikit }} \\
=\min \left(\mu_{\text {PmtTurun }}[163800], \mu_{\text {PsdSedikit }}[19500]\right) \\
=\min (0,118 ; 0,255) \\
=0,118 \\
z_{3}=165000-\left(\propto_{3}\right)(35000) \\
=165000-(0,118)(35000) \\
=160870
\end{gathered}
$$

d. Aturan ke-4

([R4]) Jika Permintaan TETAP dan Persediaan BANYAK maka Produksi Barang BERKURANG;

Operator yang digunakan adalah AND, sehingga:

$$
\begin{gathered}
\propto_{4}=\mu_{\text {PmtTetap }} \cap \mu_{\text {PsdBanyak }} \\
=\min \left(\mu_{\text {PmtTetap }}[163800], \mu_{\text {PsdBanyak }}[19500]\right) \\
=\min (0,236 ; 0,745)
\end{gathered}
$$


KARISMATIKA

p-ISSN : $2443-0366$

VOL. 4 NO. 1 APRIL 2018

$$
\begin{gathered}
=0,236 \\
z_{4}=165000-\left(\propto_{4}\right)(35000) \\
=165000-(0,236)(35000) \\
=156740
\end{gathered}
$$

e.Aturan ke-5

([R5]) Jika Permintaan TETAP dan Persediaan SEDANG maka Produksi TETAP;

$$
\begin{gathered}
\propto_{5}=\mu_{\text {PmtTetap }} \cap \mu_{\text {PsdSedang }} \\
=\min \left(\mu_{\text {PmtTetap }}[163800], \mu_{\text {PsdSedang }}[19500]\right) \\
=\min (0,236 ; 0,51) \\
=0,236
\end{gathered}
$$

Karena produksi Tetap maka $\mathrm{z}_{5}=147500$

f. Aturan ke-6

([R6]) Jika Permintaan TETAP dan Persediaan SEDIKIT maka Produksi Barang

\section{BERTAMBAH;}

Operator yang digunakan adalah AND, sehingga:

$$
\begin{gathered}
\propto_{6}=\mu_{\text {PmtTetap }} \cap \mu_{\text {PsdSedikit }} \\
=\min \left(\mu_{\text {PmtTetap }}[163800], \mu_{\text {PsdSedikit }}[19500]\right) \\
=\min (0,236 ; 0,255) \\
=0,236 \\
z_{6}=\left(\propto_{6}\right)(35000)+130000 \\
=(0,236)(35000)+130000 \\
=138260
\end{gathered}
$$

g. $\quad$ Aturan ke-7

([R7]) Jika Permintaan NAIK dan Persediaan BANYAK maka Produksi Barang 
KARISMATIKA

VOL. 4 NO. 1 APRIL 2018

BERTAMBAH;

Operator yang digunakan adalah AND, sehingga:

$$
\begin{gathered}
\propto_{7}=\mu_{\text {PmtNaik }} \cap \mu_{\text {PsdBanyak }} \\
=\min \left(\mu_{\text {PmtNaik }}[163800], \mu_{\text {PsdBanyak }}[19500]\right) \\
=\min (0,882 ; 0,745) \\
=0,745 \\
z_{7}=\left(\propto_{7}\right)(35000)+130000 \\
=(0,745)(35000)+130000 \\
=156075
\end{gathered}
$$

h. Aturan ke-8

([R8]) Jika Permintaan NAIK dan Persediaan SEDANG maka Produksi Barang BERTAMBAH;

Operator yang digunakan adalah AND, sehingga:

$$
\begin{gathered}
\propto_{8}=\mu_{\text {PmtNaik }} \cap \mu_{\text {PsdSedang }} \\
=\min \left(\mu_{\text {PmtNaik }}[163800], \mu_{\text {PsdSedang }}[19500]\right) \\
=\min (0,882 ; 0,51) \\
=0,51 \\
z_{8}=\left(\propto_{8}\right)(35000)+130000 \\
=(0,51)(35000)+130000 \\
=147850
\end{gathered}
$$

i. Aturan ke-9

([R9]) Jika Permintaan NAIK dan Persediaan SEDIKIT maka Produksi Barang BERTAMBAH;

Operator yang digunakan adalah AND, sehingga: 


$$
\begin{gathered}
\propto_{9}=\mu_{\text {PmtNaik }} \cap \mu_{\text {PsdSedikit }} \\
=\min \left(\mu_{\text {PmtNaik }}[163800], \mu_{\text {PsdSedikit }}[19500]\right) \\
=\min (0,882 ; 0,255) \\
=0,255 \\
z_{9}=\left(\propto_{9}\right)(35000)+130000 \\
=(0,118)(35000)+130000 \\
=138925
\end{gathered}
$$

\section{Defuzzifikasi}

Penegasan atau defuzzifikasi diperoleh dengan menggunakan defuzzifikasi rata-rata terpusat yaitu:

$$
\begin{gathered}
Z=\frac{\propto_{1} z_{1}+\propto_{2} z_{2}+\propto_{3} z_{3}+\propto_{4} z_{4}+\propto_{5} z_{5}+\propto_{6} z_{6}+\propto_{7} z_{7}+\propto_{8} z_{8}+\propto_{9} Z_{9}}{\propto_{1}+\propto_{2}+\propto_{3}+\propto_{4}+\propto_{5}+\propto_{6}+\propto_{7}+\propto_{8}+\propto_{9}} \\
Z=\frac{(0.118)(160870)+\cdots+\cdots+. .+\cdots+\cdots+\cdots+(0.255)(138925)}{0.118+0.118+0.118+0.236+0.236+0.236+0.745+0.51+0.255} \\
Z=\frac{388483.23}{2.572} \\
Z=151043
\end{gathered}
$$

Jadi, jumlah Produksi sabun dengan menggunakan metode FuzzyTsukamoto untuk Desember 2016 adalah sebesar 151043 pack.

Data Produksi Sabun di PT. Jampalan Baru Tahun 2016 dan Data Produksi Sabun dengan Menggunakan Fuzzy Tsukamoto 
KARISMATIKA

p-ISSN : $2443-0366$

VOL. 4 NO. 1 APRIL 2018

e-ISSN : 2528 -- 0279

Tabel 3 Data Produksi Sabun

\begin{tabular}{|l|r|r|}
\hline Bulan & $\begin{array}{l}\text { Produksi } \\
\text { Perusahaan } \\
\text { Januari }\end{array}$ & \multicolumn{1}{l|}{$\begin{array}{l}\text { Produksi } \\
\text { Fuzzy }\end{array}$} \\
\hline Februari & 130000 & 139476 \\
\hline Maret & 130800 & 146093 \\
\hline April & 1312500 & 143433 \\
\hline Mei & 155250 & 136871 \\
\hline Juni & 165000 & 153813 \\
\hline Juli & 148200 & 165000 \\
\hline Agustus & 156050 & 151934 \\
\hline September & 137800 & 146950 \\
\hline Oktober & 154440 & 151314 \\
\hline November & 164700 & 153182 \\
\hline Desember & 150800 & 151043 \\
\hline
\end{tabular}

\section{Kesimpulan}

\subsection{Kesimpulan}

1. Dari hasil perhitungan yang diperoleh menunjukkan bahwa jumlah sabun yang harus diproduksi untuk bulan Desember 2016 adalah sebesar 151043 pack.

2. Produksi sabun perusahaan berbeda dengan produksi sabun menggunakan logika fuzzy metode Tsukamoto.

3. Dengan menggunakan Metode Fuzzy Tsukamoto proses produksi berjalan lancar dan pengendalian jumlah produksi lebih stabil sehingga kemungkinan terjadi kelebihan atau kekurangan lebih kecil dibandingkan dengan yang dilakukan oleh perusahaan.

\subsection{Saran}

1. Untuk memperoleh hasil yang lebih baik, dapat menambahkan variabel inputberupa faktor lain yang mempengaruhi jumlah pemesanan, misalnya variabel biaya.

2. Dapat melakukan perhitungan yang lebih teliti dengan menggunakan metode Mamdani atau metode Sugeno, namun perhitungannya lebih rumit. 


\section{DAFTAR PUSTAKA}

[1] Kusumadewi, S., (2002): Analisis Desain Sistem Fuzzy menggunakan Toolbox Matlab, Graha Ilmu, Yogyakatya.

[2] Pardede, P. M., (2005): Manajemen Operasi dan Produksi, Andi, Yogyakarta.

[3] Ula, M., (2014): Implementasi Logika Fuzzy Dalam Optimasi Jumlah Pengadaan Barang Menggunakan Metode Tsukamoto (Studi Kasus:Toko Kain My Text), Jurnal ECOTIPE, 1(2), 36-46

[4] Setiadji (2009):Himpunan dan Logika Samar, Edisi Pertama, Graha Ilmu, Yogyakarta.

[5] Widodo, T. S., (2005):Sistem Neuro Fuzzy untuk Pengolahan Informasi, Pemodelan, dan Kendali, Edisi Pertama, Graha Ilmu, Yogyakarta.

[6] Susilo, F., (2006): Himpunan dan Logika Kabur Serta Aplikasinya, Edisi Kedua, Graha Ilmu, Yogyakarta. 